\title{
Evaluation of Teacher's Understanding and Experience About the Structure and Publication of Scientific Articles in Scientific Journals
}

\author{
$1^{\text {st }}$ Aisiah* $^{*}$ \\ Department of History, Faculty of Social Sciences, \\ Universitas Negeri Padang, Padang, Indonesia \\ aisiah.unp@gmail.com
}

\author{
$2^{\text {nd }}$ Aryadie Adnan \\ Department of Sports Education, \\ Faculty of Sports Science, \\ Universitas Negeri Padang, Padang, Indonesia \\ $3^{\text {rd }}$ Sherly Purwati \\ Department of History, Faculty of Social Sciences, \\ Universitas Negeri Padang, Padang, Indonesia
}

\begin{abstract}
The teachers understanding at junior high school (Sekolah Menengah PertamaSMP and islamic junior high school (Madrasah Tsanawiyan - MTs) of Payakumbuh district about the structure of scientific articles is relatively low and the experience of publishing scientific articles is also very poor. The evaluation result showed that there were so many teachers lack understood the contents of the parts of scientific article structure and just too litle the teachers have the experience published scientific articles at the printed scientific journals. In addition, there was no one teachers who published scientific articles in online journals. This findings were obtained
\end{abstract}

\section{INTRODUCTION}

In the Regulation of the Minister of State Empowerment of Apparatus Reform and Bureau cracy (Menteri Pemberdayaan Aparatur NegaraReformasi Birokrasi/MENPAN-RB) Republic of Indonesia Number 16 Year 2009 regarding functional positions of teachers and the number of credits was stated that one of the activities of teachers assessed for the amount of credit is the development of professionalism sustainable. Continuous professional development is an ongoing process for individual development in an effort to improve professional competence in the workplace [1], one of which is through scientific publications. from an evaluation reseach to the teachers' understanding and experience related to the structure of scientific articles and article publications. The research subjects involved 30 SMP and MTs teachers in Payakumbuh City. Data was collected through questionnaires and interviews to evaluate the teachers understanding and experience in writing and publishing scientific articles in printed and online journals. Data analysis using qualitative and quantitative descriptive approach.

Keywords-Publication, Scientific Article, Scientific Journal, Structure of Scientific Articles, Evaluation

Scientific publications are a means to help teachers introduce their writings to the public [2]. In other words, the teacher scientific publications are scientific works to disseminate ideas or research results to the public. The forms of scientific publications include; publication of scientific articles at journals, publications of lesson books, textbooks, learning modules, and translation works [3]. Scientific publications are very important for teachers in proposing promotion. Many teachers are constrained in proposing promotions because they do not have scientific publications. This can be seen from the research of the Director General of Quality Improvement of Education and Education Personnel (Direktur Jenderal Peningaktan Mutu Pendidikan dan Tenaga Kependidikan-PMPTK) in 
2009 which found $49 \%$ or 773,781 teachers were in the level III group. Whereas teachers at group IV level were only $37 \% ; 12$ teachers are at group IV/e level, 15,000 teachers are at group level IV/b to IV/d, and 569,709 teachers are at group IV/a level. In addition, there are still many teachers at the IV/d level. This is due to the relatively low credit amount of scientific publications.

The lack of teacher scientific publication credit numbers indicate that teachers rarely write scientific articles. Roza [4] present evidence which concern when asseessing teacher certification portfolios in West Sumatra. Of the 64 documents assessed, $77.4 \%$ did not meet the assessment indicators, including the publication of articles at scientific journals. It means that the teachers rarely doing the research, write scientific articles, and publish at in scientific journals. This is support by Kartowagiran's research findings [5] that teachers very rarely carry out professional supporting activities such as research, writing scientific articles, or scientific publications.

The question that arises then is why this is happen, whether the teachers not yet have a good understanding about scientific articles, including it writing structure or the teachers not yet the experienced related to article publications at scientific journals. Further investigation is needed in the form of evaluation research. Thus, this study aims to monitor teachers understanding about the structure of scientific articles and the experience of articles publication at scientific journals. This research is important because article publications at scienific journals is needed to support the professional performance of the teachers [6] and are also become one of the requirements for submission of the teacher promotions. Through this research the information about teachers understanding and experience related article writing structure abd publication of scientific articles can be obtained. Furthermore, this information can be used by policy makers (head educational office) to provide technical guidance to teachers so they can write good articles and publish them at online scientific journals, so that problems of teacher promotion can be overcome. Through the improvement of teacher ability in wriring scientific articles teachers can develop their professional abilities while improving the quality of learning [7].

\section{METHOD}

This research is an evaluation research to monitor teachers' understanding of the structure of writing scientific articles and mapping teacher experiences related to the publications of articles at scientific journals. Research subjects were 30 junior and MTs high school teachers in Payakumbuh City (8 male teachers and 22 female teachers). Twenty people among other were junior high school teachers and ten others were MTs teacher. Data were collected using a questionnaire containing closed questions and short stuffing written by the teacher according to their experience and understanding. The closed questions be provided the answers alternative chosen by the teacher according to their experience. On the short stuffing provided the space for the teacher wrote their understanding about the structure of scientific article writing. In addition, interviews were also conducted to complete the data collected about the teacher's experience related to articles publication at the scientific journals and so teacher's understanding about the structure of writing scientific articles. The data were analyzed by using descriptive quantitative and qualitative approach to illustrate the research findings.

\section{RESULTS AND DISCUSSION}

Scientific articles are factual papers about a problem obtained from research and non-research results and are arranged systematically based on scientific writing methods. The aim is to offer problem solving, convey ideas, and educate [8]. Scientific articles are a form of ongoing professional development efforts as listed in Minister of Education Regulation No. 18 of 2007 concerning teacher certification regarding promotion. The following are the eksplanations of the results of evaluation research related the teacher's under standing about the structure of scientific articles writing and the teacher's experience in article publication at scientific journals.

\section{Teachers Understanding related Structure of Scientific Article}

The research findings show that the understanding of junior and MTs high school teachers in Payakumbuh City regarding the structure of scientific articles is very low. SMP and MTs teachers who are the subject of research 
generally do not understand the structure of scientific articles for publications in scientific journals. Of the 30 teachers investigated, only 2 $(6.7 \%)$ understood the structure of scientific articles, $10(34.4 \%)$ lacked understood, and $18(60 \%)$ did not understand the structure of scientific articles at all. This means that more than half number of teachers do not understand the structure of scientific articles, what else understands them well. One third of the 30 teachers are less less understand the structure of scientific articles. Thus it can be said that majority $(94.4 \%)$ of teachers did not understand the structure of scientific articles. The following is an overview of SMP and MTs teachers undestanding regarding the structure of scientific articles.

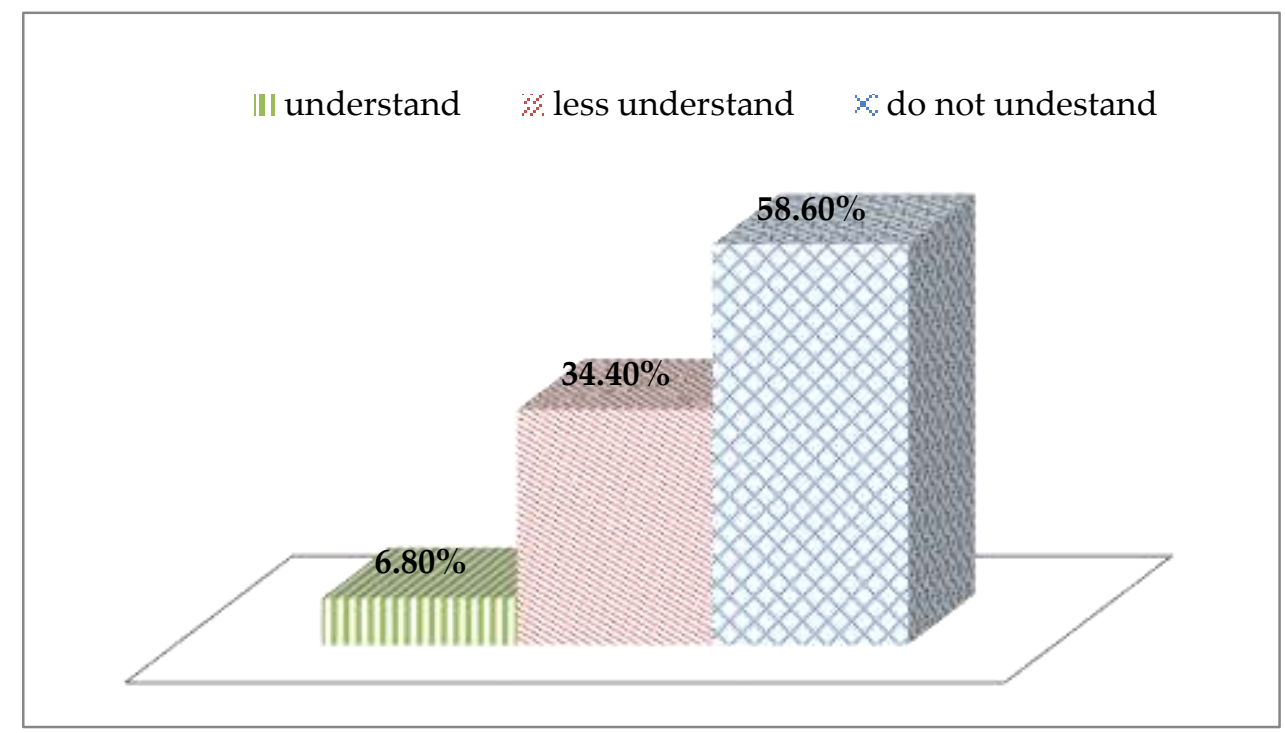

Figure 1. Teacher Understanding Regarding the Structure of Scientific Article

Scientific article is an academics argumentative description by the lecturers, researchers, and teachers for revealing information about a particular subject or field [9]. Scientific articles have a standard structure consisting of titles, abstracts, keywords, introduction, methods, results and discussion, conclusions and suggestions, and bibliography. The findings of this evaluation research prove that most of the SMP and MTs teachers did not yet understand the structure of scientific articles mentioned by Personal \& Delfy [9]. The following is the description of the teachers' understanding of the structure of scientific articles.

\section{a. Title}

Teacher's understanding about the title article criteria, most teachers stated that article title were 'short, clear and interesting'. However, there are also teacher understanding were wrong when the teachers are asked to mention the title article criteria. The teachers said 'written in capital letters, provocative, adding phrases, new results'. According to Peat et. al [10], the effective article titles must fulfill the following criterias; 1) discuss the main problems of scientific articles, 2) start with the subject of scientific articles, 3) accurate, unambiguous, specific, and complete, 4) no abbreviations, except known by the reader, 5) interest the readers. Article titles written by teachers have not been fully meet the elements of effective titles. The title written by Mr. A:

"Increasing English Learning Activities and Outcomes at Basic Competencies related Comparison Degrees Through Scientific Approach Discovery Learning Model with the Group Discussion Methods at Even Semester Class VIII.1 SMPN 8 Payakumbuh academic year 2018/2019"

This title is not effective because it's too long. If the title too long, there are many words are not important so it doesn't interest the reader. On the other hand too short title is also ineffective because it often use general words and do not provide strong information about research focus. For example the title written by Mr. R; "The Formation 
of Child Characters in the Digital Era". This title too general and research subject wasn't specific. Good title consists of a number of words that represent variables or key words of the reseach. Title writing is no more than 15 words if written in Indonesian and 10 words if written in English [11]. For example the title was written by Mrs. Z; "Improving Students Reading Ability Grade VIII Using Literacy Corner Media".

\section{b. Abstract}

Abstract is a part of the structure of scientific articles after the title. Teachers' understanding of abstract content also varies. There are the teachers who understand that abstracts consist of 'background, theoretical basis, results of literature study'. This understanding wasn't fully right. In addition, there are also teachers understood that abstracts containing 'problems and solutions', while others teachers stated that abstracts containing 'conclusions of the research results'. This understanding is not completely correct. Some other teachers understood that abstracts containing; summary; precis; general description, important things from the whole articles' contents. This understanding is too general, does not reflect abstract specific content. There are only two teachers who understood correctly the content of abstract section. These two teachers stated abstracts containing 'the problems, objectives, methods and research findings'.

The understanding of both teachers is in line with Gunawan \& Microsurgesy idea [11] [12] that abstract subsections containing research problems, research objectives, research methods used, and research results obtained. Abstract of scientific article usually written 100-200 words in one paragraph. When the teachers are asked writing abstract of articles, the the results have not been satisfactory. This can be seen from the example of abstract written by Mr. YM as follow.

"Now there are many cases that occur between parents and children whose parenting pattern is no longer correct. So many cases occur among children and even adolescents who have violated existing norms and rules."

The abstract written by Mr.YM has not fulfilled main elements of an abstract. Mr. Y only explained the research problem about the effect of parenting pattern to the children. Mrs. Y didn't write down the objectives, methods, and results of her research. This abstract wasn't informative yet. A little different from Mrs. Y, Mrs. Z has written the objectives, and research methods, but there wasn't research problems. The method section hasn't been explained in detail. Research results (findings) didn't seen.

\begin{abstract}
"reading ability is one of the most important abilities in education system. This study purpose is describe the improvement students reading skills grade VIII using literacy corner media. Data obtained from observations of learning activities." Kata Kunci
\end{abstract}

The evaluation results illustrated that some teachers didn't understand about the keywords section. One of them, Mrs. D wrote 'Improving teacher pedagogical ability' as her article keyword. It wasn't reflected keyword because keywords is a word or phrase, not a sentence. This sentence is part of article title at glance. Nevertheles, there are also the teachers who have understood the article keywords. For instance, Mr. A wrote keywords consisting of or phrases, ie; 'learning activities', 'scientific learning', 'learning discovery models', english learning'.

\section{c. Introduction}

The elements that must be present in the introduction section include; 1 ) research problems, 2) initial studies relevan related research problem, 3) proposed solutions, 4) research objectives, and 5) expected results [11]. This evaluation result show that the teachers didn't fully understand the elements of introduction section. Some teachers stated the introduction section containing the background of the research. This understanding wasn't not fully correct. Only one teacher (Mrs. R) absolutly understood and mentioned the introduction section contained the research problem, initial research study, urgency and research objectives. In general, the teachers only understood that the introduction section just containing background. The teachers weren't understand that beside the research background, the introduction part also containing the information about prior study, the urgency and research objectives. These elements lost from 
teacher's mind. This fact can be read on the introduction article written by Mrs. Z.

\begin{abstract}
"The low ability in reading is still become big problem that hard to overcome in education in Indonesia. Many factors affecting, including family education. The lack of family role in introducing reading material at home also contribute to this problem. This study aims is getting illustration about improving students' reading skills through literacy corner media in the classroom".
\end{abstract}

The contents of the introduction section written by Mrs. $Z$ describe the problem and research objectives only, relevant studies and research urgency are missing. Beside that the problem written wasn't relevant with the study purpose. Mrs. Z explained factors caused students low ability in reading is due lack of family roles, but the research aim written was getting illustration about improving students' reading ability through the literacy corner. It shows that research problem didn't match with the research aim. Ideally the problem must be relevant to the study purpose. Writing research problems should be contained theory, supporting data, and prior research [13] and the urgency of the study to strengthen the contents of introduction section.

\section{d. Method}

In general evaluation results show that most teachers understand the contents of method section, i.e 'the way of problems solving'. Almost teachers understood that method section contained 'the way the data collected and analyzed'. This understanding wasn't correct entirely, except for a few teachers who truly understood the elements of method section. For instance, Mrs. E mentioned method section consist of 'types of research, research procedures, data sources, data collection and analysis. This understanding supported by Hoogenboom \& Manske [14] who stated that the contents of method section were explanation of the research design and procedures. The details include; 1) population and research equipment, 2) what was done during the study, 3) rules/ways of doing research, 4) results and measurement techniques, and 5) ways of data analysis.

Teacher's understanding that was still mistaken about the contents of the metohod section can be seen from their writing. In the method section the teacher frequently only wrote research type, other information about the elements of method section like population or respondents, data collecting were rare explained in detail. Ideally in the method section the teachers should also explain the procedures or steps of the research, how to collect and analyze the research data.

\section{e. Results and Discussion}

Generally, teachers understand that the results and discussion sections containing 'results of hypothesis testing', 'results of data analysis', 'reviews of research results'. The mistaken teacher's understanding can be seen from several their statements about the contents of result section and discussion i.e 'problem exposure and its solution', 'action', 'important information'. These statements were mistaken and also showed misunderstanding about the contents of the results section and discussion and the contents of the method section. The Statement of 'problem exposure and its solution' was the content of introduction section. While the statement of 'action' was the conten of the method section. Only a small proportion (two teachers) understand correctly that the results and discussion sections containing data exposure and information on research findings. This understanding in line with the opinions of Hoogenboom \& Manske [14] which stated that the results and discussions were the exposure findings of data analysis and review or the interpretation of results and comparison with theories or similar research results [11].

\section{f. Conclusions and References}

Conclusions and references are the last section of an scientific article. The teacher's understanding this contents section were generally correct. Most of teachers stated that the conclusions section contained summary, the essence of the results study. In line with the opinion of Gunawan et al. [11] that simpulan Conclusions are summary and affirmation of the research findings. But it should be remembered that the conclusions weren't only a restatement of the research results, but also the consistency of several final statements (maximum two sentences) that can be referred [15] and reflected research finding [14]. 
The teacher's understanding about references was quite good. Most teachers already understood that the contents of references section were sources of references of articles, It was just the teachers assume that references was only from books or blogs. Even though there are many other types of references, for instance; research articles and reports, scientific magazines, regulations/ policies and others. Scientific article at journals as references actually can improve the quality of teacher scientific articles, but the evaluation result shows that teachers weren't used it frequenly even though scientific articles are the most recent reference material [16]. Many teachers still used old and outdated references although strongly recommended using references at least the last 10 years. Besides the teacher is often mistaken with the style of references writing. There are many of styles references writing, such as Harvard style, APA style, IEEE style and others. junal Scientific journals use different reference writing styles [13]. Evaluation results show that teachers haven't yet familiar with various types of bibliography writing styles, so they were often mistaken in writing them. In addition, teachers also very rarely use tools to manage references such as Mendeley, EndNote and others. However, understanding is not enough. The teachers should try using tool in working scientific articles and publication.

Understanding and experience are related to one another including in the writing and publication of scientific articles. Understanding can be shaped by repeated experiences, conversely repeated experiences of course impacted on better understanding. The more experience in writing and publishing scientific articles, of course the better the understanding of writing scientific articles. This is evidenced by research findings regarding the evaluation of teacher experiences in scientific publications below.

\section{Teachers' Experiences in Training and Writing Scientific Articles}

The findings of this evaluation research indicate that teachers' understanding about the structure of writing scientific articles is still low (poor). The low of teacher understanding also in line with the lack of teacher experience in writing and publishing scientific articles. This can be proven from the evaluation results which shows that of 30 teachers, only 8 teachers $(23.7 \%)$ had experience writing scientific articles and 22 teachers (69.2\%) had never written a scientific article at all. Some of their reasons i.e no time for writing, not understood how to research and write scientific articles, and too busy with school activities. Ideally, as educator the teachers should have the ability writing scientific articles to improve the quality of learning [17]. Actually, the government through the Ministry of Research, Technology and Higher Education has published guidelines of technical guidance implementation of training writing scientific articles. Training writing scientific articles is one of the activities that can help teachers improve their ability in write scientific articles [7]. Figure 2 shows the evaluation result related too little teacher experience following the training in writing scientific articles.

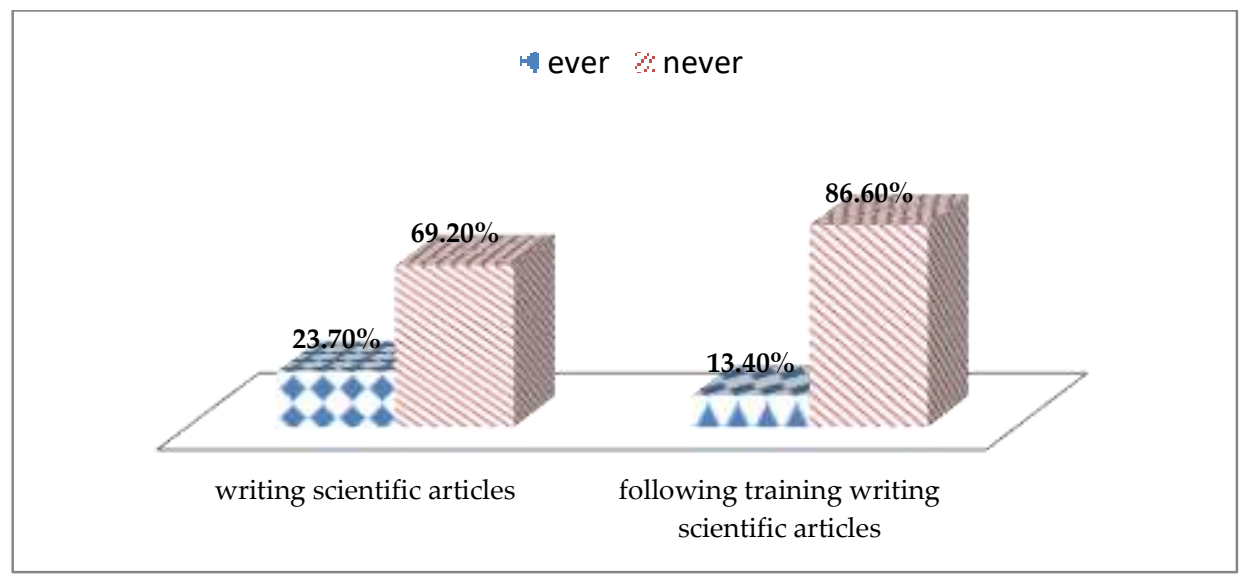

Figure 2. Teacher experience following training and writing scientific articles 
$86.6 \%$ the teachers who were the subject of the study had never follow training in writing scientific articles, except for $13.4 \%$. Only $6.6 \%$ followed the training and at most just twice training. Very often after the training activities ended no follow up to monitor the continued of teachers writing scientific articles. The knowledge gained from training activities wasn't well applied and impacted on the teachers lack understanding related the structure of scientific articles. Teachers were lazy and rarely write scientific articles. It can be seen from the evaluation result number scientific articles produced by teachers. Research findings indicated the number of articles written by teachers were very little. Of 30 teachers, only two teachers $(6.6 \%)$ produced two articles, 7 teachers $(23.4 \%)$ produced one article, 21 others (70\%) didn't produce an article at all. This Evidence shows the fact that the number teachers scientific articles publication too little.

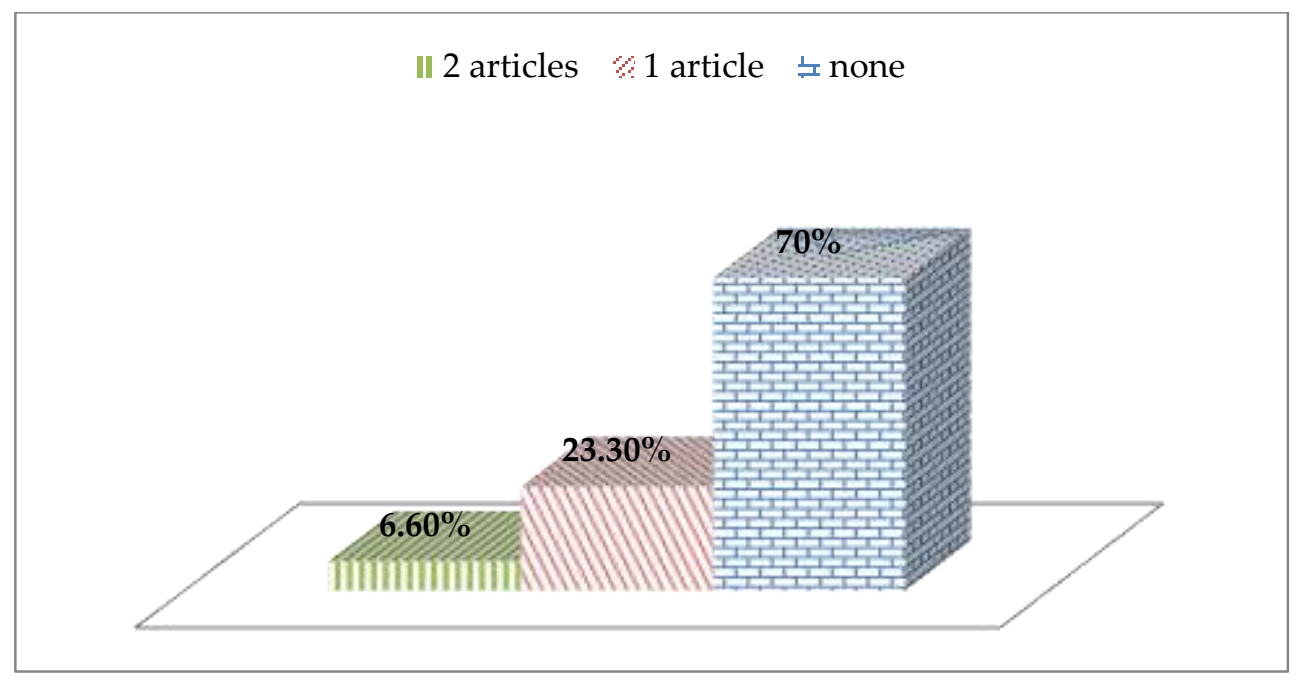

Figure 3. Teacher experience produced scientific article

Figure 3 above reflected someone understanding related to his experience and otherwise. These two variables show reciprocal relation. The teachers who never written scientific articles were due to several factors. First, the teacher lacks understanding the structure of scientific articles. Mrs. BS stated "We don't understand the concepts of scientific articles, we don't understand the appopriate methods". Another comment also stated by Mr. WN, "in principle, we don't understand the concept of scientific wor, our understanding scientific about articles is inadequate, education and training have never been followed".

Teachers' low understanding about the structure of scientific articles can be proven from their article plan they written. When teachers are asked writing their research article plan on a sheet of paper, there are still the teachers who have not been able to write completely and correctly, and some even return blank papers. It indicate the culture of writing has not been a concern and priority for the development of sustainable careers and promotion/position for teachers in schools. The teacher difficult in thinking systematically, so the logic of scientific article he wrote was unclear.

Second, lack of motivation writing. Motivation is someone strength or intention in order enthusiastic doing an activity sourced both inside and outside individual [18]. The results of this study indicate that teachers internal motivation were low. Most teachers still think writing scientific articles was difficult thing to do. Publication of scientific articles hasn't become a personal need. The teachers still regarded publication of scientific articles just required when applying promotion and meet the sum of credit score. Actually, scientific articles not only for fulfillment of credit scores, but also exhibit their professional productivity as a teacher. Third, time constraints. Full teaching schedule and busyness at home become one of the reason the teachers rare write scientific articles. Writing scientific articles of course require sufficient free time [19] but, if the teacher has a strong motivation, time and busyness wasn't a 
reason for teachers didn't write scientific articles. Fourth, technological stuttering. Actually, technology has made easy for writing scientific articles, but it hasn't used by the teacher fir instance to looking for references. The teachers more used old printed books and never used search engine technology to obtain a variety up-to-date references in the form of e-books, research articles, papers and other types of references. Using internet through google scholar channel and ResearchGate can facilitate teachers to find higher quality references.

\section{Teachers Experience related Articles Publication at Scientific Journals}

The evaluation results show that teacher's experience related articles publication at scientific journals is still rare. Scientific journal is media that function was disseminating the research results or significant discoveries in certain fields of science [10]. Scientific journals published in print and online [20]. ThisThe research result found that teacher's experience submitting articles at printed journals and online journals until published very limited and far from the expectations. The research findings showed that only 5 teachers $(15.38 \%)$ have ever been submitted articles to printed scientific journals, and 25 other teachers $(88.46 \%)$ had never. While the teacher's experience related article publications at electronic scientific journals hasn't existed at all even though the latest trends of publications at scientific journals are currently more sugested at online journals.

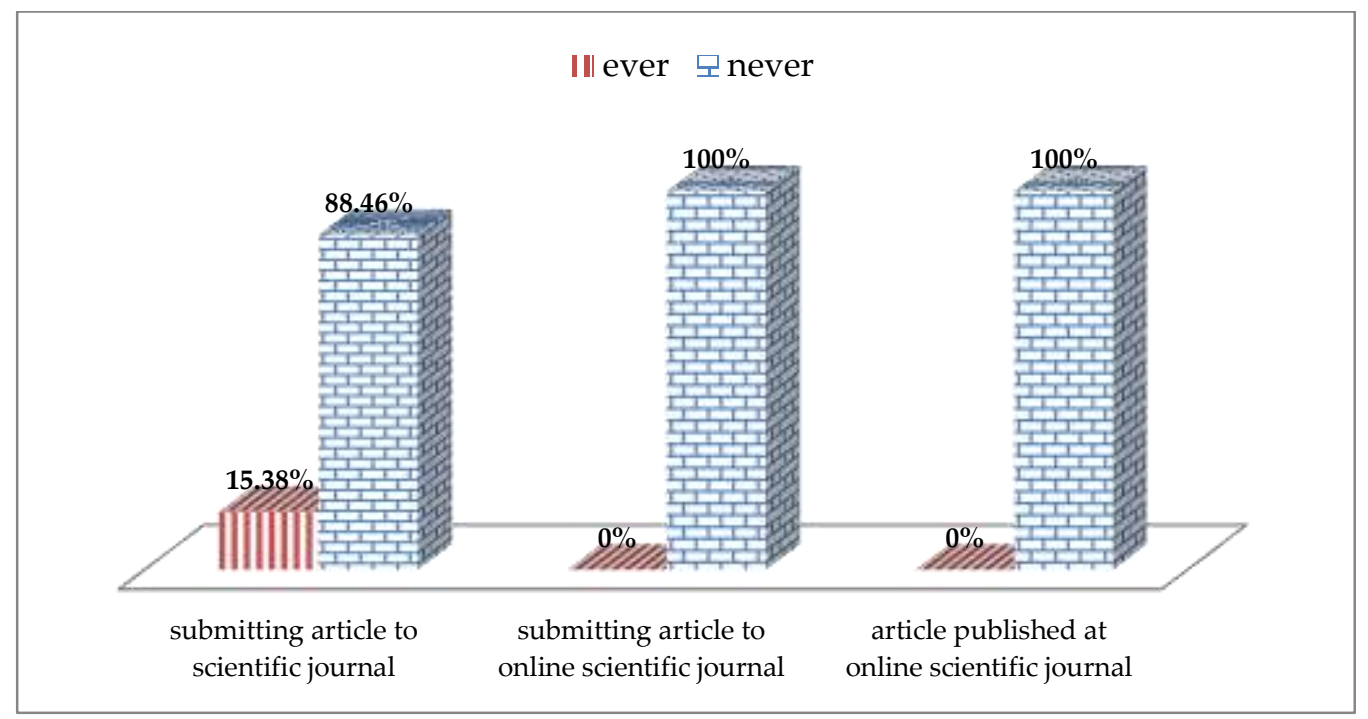

Figure 4. Teacher's Publication Experience at Scientific Journals

The lack of teacher's experiences published articles at online scientific journals were caused teachers didn't knows and very rarely accessing various online journals available on the internet. Instead of knowing a number of relevant journals to their scientific study, the teachers even couldn't distinguished between scientific articles and scientific journals also. Almost all teachers have not been able to distinguish between journals and articles, even teachers consider journals the same as articles. Scientific journals as a collection of several scientific articles have not been understood by teachers and teachers assume that articles are journals. Thus, of course the teachers didn't know characteristics of suitable scientific journals and available on the internet for their articles publication. Aisyah and Mahanani [21] explained several characteristics scientific journals that need to be considered by teachers, such as; 1 ) educational journals (focusing on aspects of learning, evaluation, research, management, and certain fields of study; 2) special journals that only present the results of research or community service; 3) accredited journals and non-accredited.

\section{CONCLUSIONS}

Based on the results of an evaluation research on SMP and MTs teacher's understanding and experience in Payakumbuh City about the structure of scientific articles and the experience of publishing 
articles at scientific journals it can be concluded that teachers understanding and experience still lack and too little. In general, the results of the evaluations to the teachers' understanding and experience about publication at scientific journals can be divided into three categories, i.e the teachers who haven't understanding and no experience about articles publication at scientific journals; teachers who have understanding, but have no experience; and teachers who have both understanding and experience of publishing articles at scientific journals. These teachers need to be supported according to their each needs in the form of article writing training activities and facilitating articles publication process at online journals. Further research suggestions i.e investigating teacher knowledge regarding the process of publishing articles in online journals ranging from submit, review process, revision to published.

\section{ACKNOWLEDGMENTS}

Acknowledgments addressed to all parties those who have assisted in the research process, especially the SMP and MTs teachers at Payakumbuh City who have been willing to become research respondents. The researcher also expressed his thanks to the ICCSGT publication committee for helping the process of publishing this article.

\section{REFERENCES}

[1] Sujianto, S., Mukhadis, A., \& Isnandar, I. (2013). Pengembangan Profesionalitas Berkelanjutan Guru Bersetifikat Pendidik di SMK Rumpun Teknologi. Teknologi dan Kejuruan: Jurnal teknologi, Kejuruan dan Pengajarannya, 35(1).

[2] Jatmiko, W., Santoso, H. B., Purbarani, S. C., Syulistyo, A. R., \& Purnomo, D. M. (2015). Panduan Penulisan Artikel Ilmiah. Jakarta: Universitas Indonesia.

[3] Setiadi. (2015). Publikasi Ilmiah Guru. Yogyakarta: Deepublish.

[4] Miqdad, Alfarisyi. (2015). Kurangnya Pembinaan Terhadap Guru SMA. Kompasiana. [Online]. Retrieved from https://www. kompasiana.com/miqdadalfarisyi/54f5eef0a33 311c5028b4580/kurangnya-pembinaanterhadap-guru-sma [Diakses: 15 Januari
2020].

[5] Kartowagiran, B. (2011). Kinerja Guru Profesional (Guru Pasca Sertifikasi). Jurnal Cakrawala Pendidikan, 3 (3).

[6] Usman, Uzer. (2011). Menjadi Guru Profesional. Bandung: Remaja Rosdakarya.

[7] Rahim, F. R., Festiyed, F., Yohandri, Y., Yulkifli, Y., \& Djamas, D. (2017). Studi Pengalaman Guru-Guru MTSN 6 Pesisir Selatan dalam Penulisan Karya Tulis Ilmiah Guna Meningkatkan IPTEK Masyarakat Serta Mewujudkan Guru yang Profesional. Jurnal Eksakta Pendidikan (JEP), 1 (2), pp. 80-87.

[8] Binti Ismail, N. A. (2011). Penguasaan Penulisan Karangan Bahasa Melayu dari Perspektif Komunikatif in Seminar Penyelidikan, pp. 1-12.

[9] Pribadi, B. A., \& Delfy, R. (2015). Implementasi Strategi Peta Konsep (Concept Mapping) dalam Program Tutorial Teknik Penulisan Artikel Ilmiah bagi Guru. Jurnal Pendidikan Terbuka dan Jarak Jauh, 16 (2), pp. 76-88.

[10] Derntl, M. (2014). Basics of Research Paper Writing and Publishing. International Journal of Technology Enhanced Learning, 6 (2), pp. 105123.

[11] Gunawan, Suryoputro, Riadi S., Ali, S. (2012). Menulis Artikel untuk Jurnal Ilmiah. Jakarta Selatan: Uhamka Press.

[12] Microsurgery. (2011). A Guide to Write A Scientific Paper for New Writers. Wiley Online Library. 28 November 2011 [Online]. Retrieved from wileyonlinelibrary.com DOI 10.1002/ micr.20960 [Diakses: 1 April 2020].

[13] Farid, M. (2017). Menulis Artikel Ilmiah: Proses Menemukan Ide Hingga Publikasi. Makalah Seminar Penulisan Artikel Ilmiah, Perhimpunan Pelajar Indonesia (PPI) NPUST, pp. 1-9.

[14] Hoogenboom, B. J., \& Manske, R. C. (2012). How To Write a Scientific Article. International Journal of Sports Physical Therapy, 7 (5), pp. 512.

[15] Sengupta S, Shukla D, Ramulu P, Natarajan S, 
Biswas J. (2014). Publish or Perish: The Art of Scientific Writing. Indian Journal of Ophthalmology, 62 (11), pp. 1089-1093.

[16] Azwar, M., \& Amalia, R. (2017). Pemanfaatan Jurnal Elektronik Sebagai Sumber Referensi Dalam Penulisan Skripsi Di Institut Pertanian Bogor, Libraria, 5(1), pp. 1-24.

[17] Pahmi, P., Ardiya, A., Syahfutra, W., Wibowo, A. P., Niah, S., \& Febtiningsih, P. (2018). Pelatihan Penggunaan Mendeley untuk Referensi dalam Menulis Karya Ilmiah bagi Guru SMA Handayani Pekanbaru. Jurnal Pengabdian UntukMu NegeRI, 2(2), pp. 35-39.

[18] Sukarno, S. (2016). Kendala dan Upaya Pengembangan Keprofesian Guru Sekolah Dasar Melalui Kegiatan Penulisan Karya
Ilmiah. Prosiding Seminar Nasional Inovasi Pendidikan, pp. 601-610.

[19] Noorjannah, L. (2015). Pengembangan Profesionalisme Guru Melalui Penulisan Karya Tulis Ilmiah Bagi Guru Profesional di SMA Negeri 1 Kauman Kabupaten Tulungagung, Jurnal Humanity, 10(1), 2015.

[20] Lancaster, F. W. (2017). The Evolution of Electronic Publishing. Library Trends, 43 (4), pp. 518-527.

[21] Aisyah, E. N., \& Mahanani, P. (2017). Pelatihan Menulisan Artikel Ilmiah Bagi Guru Sekolah Dasar dan Taman Kanak-Kanak Kecamatan Tajinan Kabupaten Malang. Abdimas Pedagogi: Jurnal Ilmiah Pengabdian kepada Masyarakat, 1(1). 